\title{
'What a howl there would be if some of our folk were so treated by an enemy': The evacuation of Aboriginal people from Cape Bedford Mission, 1942
}

\author{
Jonathan Richards
}

One fine and warm winter morning in May 1942, the Poonbar, a medium-sized coastal vessel, steamed into the Endeavour River at Cooktown, North Queensland, and berthed at the town's wharf. After she tied up, over 200 Aboriginal people carrying a small amount of personal possessions emerged from a cargo shed on the wharf. The people were herded by about a dozen uniformed Queensland police as they boarded the boat. The loading, completed in just over an hour, was supervised by three military officers, two senior police and a civilian public servant. As the ship cast off, the public servant, who boarded the boat with the Aboriginal people, threw a coin to a constable on the wharf and shouted 'Wire Cairns for a meal!' Unfortunately, the wire did not arrive at Cairns in time, and as a result the party of Aboriginal people was given little food until they reached their destination, 1200 kilometres and two day's travel away.

The war between Japan and the Allies was nearing Australia, and this forced evacuation of Aboriginal people was deemed necessary for 'national security' reasons. Although the evacuation has been written about by a number of scholars and Indigenous writers, the reasons for the order have not, I believe, been clearly established. Similarly, the identity of the forces - military or otherwise - that carried out the evacuation have never been conclusively determined. This article addresses these two issues alone.

Japanese forces captured Singapore in February 1942, landing in New Guinea soon after. Darwin was bombed for the first time on 19 February, followed by more air raids in March and April. ${ }^{2}$ In late March, the Deputy Director of the Queensland Department of Native Affairs, Cornelius O'Leary, wrote to the Home Secretary in Brisbane advising 'the evacuation of Cape Bedford aboriginals may be necessary':

It is understood that the military authorities are considerably exercised by reason of the location and control of this Mission, and that representations

1 Andrew Standfield Sampson at Cooktown to Mrs Bennett at Eumundi, 18 May 1942, Queensland State Archives [henceforth QSA], SRS 505/1/4685.

2 Unknown 1942: 155. 
are being made by Major Lawnton [sic, Laughton], Chief Intelligence Officer, Victoria Barracks, for the removal of the Mission inmates to a location south of the Tropic of Capricorn. It is considered by Military Authorities that the alleged assistance rendered the Japanese Army in New Guinea by German missionaries could be repeated at Cape Bedford Mission, and the Authorities are not prepared to take the risk of such. ${ }^{3}$

These allegations of missionary collaboration and the circumstances that brought O'Leary to this conclusion, which ultimately resulted in the forced evacuation of over 200 Aboriginal people from the Cape Bedford Aboriginal Mission, are worth serious consideration.

Ultimately, the recorded reasons for the evacuation clearly show that military needs were more important than the mission residents. This article, exploring the factors that resulted in this 'deportation', arises from research into the origins of the evacuation order, and into the identity of the forces that cleared the Cape Bedford Mission of Aboriginal residents. Specifically, what were the reasons for the removal? Was the evacuation ordered by the Australian military? Were any American soldiers involved or was this a domestic affair, and why have some people believed that Americans took part?

The removal of the Cape Bedford people was arguably the only forced mass evacuation in Queensland during wartime. Although many individuals and families in northern Australia self-evacuated as war approached, this was the only community that was completely displaced. According to historian Mark Copland, the Cape Bedford removal was also unique because it was the only time that the state government took action as a result of federal government intervention. ${ }^{4}$

There were other comparable events in Australia during the Second World War. Aboriginal missions in Western Australia and the Northern Territory were evacuated, and some missionaries were interned. Soldiers took charge of the (Lutheran) Beagle Bay Mission in 1940, but no armed forces were involved in the voluntary evacuation of the (Methodist) Croker Island Mission during April 1942. Some Aboriginal people were evacuated from Mornington Island, while other families remained there throughout the war. Many Thursday Island residents fled south in January 1942, but as Elizabeth Osborne notes, 'no one was forced to leave' ${ }^{5}$ Furthermore, Indigenous people throughout Torres Strait were placed 'beyond the front line of Australia's defence' after Queensland's Director of Native Affairs gave orders for them not to be evacuated. ${ }^{6}$ Although 90 Hammond Island residents from Torres Strait were removed to the Darling Downs and 200 'coloured residents' from Thursday Island were taken to Cherbourg (both in southern Queensland) for the duration of the war, other northern missions were left undisturbed.

3 O'Leary to Home Secretary, 23 March 1942, QSA, SRS 505/1/4685, letter 3964 of 1942.

4 Copland 2005: 116.

5 Osborne 1997: 22.

6 Osborne 1997: 91. 
Despite this ad-hoc evacuation policy, a steadily growing anxiety about a Lutheran mission, established and staffed by German missionaries, in what was rapidly becoming a critical operational area for the defence of Australia, culminated in the removal of Indigenous people from Cape Bedford Mission and the internment of the missionaries. Most who have written about this event, including several Aboriginal authors, accept this apparent circumspection as the primary or sole reason for the mission's total evacuation. For example, Aboriginal activist Noel Pearson says 'security' was the 'most likely reason' for the removal. ${ }^{7}$ However, any thorough investigation of these details must start by considering the reasons for the evacuation, and then turn to reviewing the surviving records.

Three main points are discussed in this article. These are, firstly, the general panic due to fear and threat of invasion, compounded by rumours (later proven untrue) of missionaries assisting the enemy. Secondly, the unique situation of the Cape Bedford people, mistreated by authorities and not given sufficient time to take their personal belongings when evacuated on a long and traumatic journey. And lastly, the rapid construction of a military airfield - immediately after the evacuation - on land previously occupied by the Cape Bedford Mission.

Some refer to the removal as 'exile'. Others stress the fear of Aboriginal collaboration. Pearson states the removal was made 'by order of the Military Authorities, acting with the knowledge and collaboration of the Department of Native Affairs' but does not fully explore the reason for the removal. ${ }^{8}$ He notes that many people believed they were taken south 'for their own protection from the Japanese'. ${ }^{9}$ Other Aboriginal people thought they were removed because of a fear that they might assist Japan. Pearson concludes that the 'utilisation of labour' may have been 'one of the reasons' for the evacuation, although the 'relevant documents' were 'unavailable' at the time of his writing. ${ }^{10}$

Kirstie Close, who wrote about Cape Bedford during the Second World War in her Master's thesis, concludes that the evacuation was related to labour, land, autonomy and government control. ${ }^{11}$ She believes the issue of labour was more important than protection, arguing that if the safety of Indigenous people had been the real reason for the removal, other missions would have been evacuated as well. ${ }^{12}$ Close acknowledges that land was important, and that an aerodrome was constructed on the mission's site, but contends that labour was the main issue:

7 Pearson 1998: 204.

8 Pearson 1998: 203.

9 Pearson 1998: 203.

10 Pearson 1998: 214-215.

11 Close 2009: 7-8.

12 Close 2009: 49-51. 
The war became a justification for the further appropriation of land and supreme control over Aboriginal labour. The desires for land and labourers far outweighed any thought for the Mission resident's safety. ${ }^{13}$

There were, obviously, important reasons for the evacuation apart from the fear of Aboriginal 'fifth-columnists' assisting a Japanese invasion.

\section{The Cape Bedford Lutheran Mission}

Cape Bedford is situated about 30 kilometres north of Cooktown, Queensland's most northerly port. Established in 1873 after gold was discovered on the Palmer River, the town soon became a major administrative and commercial centre, but Cooktown was effectively isolated from other North Queensland centres. A railway connected Laura in the hinterland to the port, but there were no usable roads connecting the town with other centres and all supplies were brought by coastal ships. Until air travel became possible in 1937, passengers mainly arrived or left by sea.

The first Aboriginal Reserves in Queensland were proclaimed in the late 1870s, and the Cape Bedford Reserve followed in $1881 .{ }^{14}$ However, in the same year, detachments of Queensland's notorious Native Police killed large numbers of Aboriginal people in the area following the death of Mrs Watson from Lizard Island, 50 kilometres north of Cape Bedford, close to the mission's boundary. ${ }^{15}$ In 1885, Johann Flierl, a Lutheran missionary from South Australia, established the Cape Bedford Lutheran Mission. ${ }^{16}$ Flierl left in 1887 and was replaced by Pastor George Schwarz, known by Aboriginal people as 'Muni'. He renamed the mission, now called 'Hope Valley', and remained for more than 50 years. ${ }^{17}$

All Aboriginal and Torres Strait Islander people in Queensland were placed under The Aboriginals Protection and Restriction of the Sale of Opium Act 1898 (Qld), which meant that every aspect of their lives, especially education, employment, residence and marriage, were totally controlled by the state's network of Aboriginal Protectors. The old ways were largely gone. Under the Act, government gained the power to move individuals and families wherever, and whenever, officials saw fit. ${ }^{18}$

Cape Bedford became the home for Aboriginal children and adults 'removed' during the early decades of the twentieth century by government officials and police from other parts of Queensland, particularly Cape York Peninsula, and

13 Close 2009: 47, 59.

14 Queensland Government Gazette, 1 December 1934, Volume 29, no 26: 390.

15 Haviland with Hart 1998: 35; Falkiner and Oldfield 2000; Richards 2008: 42.

16 Haviland and Haviland 1980: 126.

17 Evans 1972.

18 Copland 2005: 15-16. 
the state's northern and western regions. ${ }^{19}$ By 1934 the reserve covered 225,300 acres, including settlements at the Eight Mile, near Cooktown, and Spring Hill, further north near the coast. ${ }^{20}$

As this article describes, most of the Aboriginal people from the Cape Bedford Mission were forcibly taken in the winter of 1942 to the Woorabinda Aboriginal Settlement in Central Queensland, inland from Rockhampton, and between Emerald and Moura. ${ }^{21}$ Numbers of the Cape Bedford people died while at Woorabinda and the survivors were not allowed to return to the mission until several years after the war. They came back to a new settlement called 'Hopevale', about 25 kilometres from the old mission, gazetted as an Aboriginal Reserve in September 1952. Roy McIvor, one of the last surviving evacuees, describes the confusion this caused:

It is not clear why the Hope Valley people were moved. Some thought it was because of their allegiance to Muni [Schwarz], while others believe it was because of rumours that the Hope Valley bama [Aboriginal people] were communicating with the Japanese through morse code and smoke signals. ${ }^{22}$

Roy McIvor's remarks about the reasons for the evacuation are particularly insightful:

There is also speculation that it may have been because the military wanted to move their landing strip from Four Mile to the more strategic site of Muni's land at Eight Mile. The military did this only a few months after the Hope Valley people were taken away. ${ }^{23}$

One other writer arrived at a similar conclusion. Derek Townsend, a biographer of Queensland Premier Johannes Bjelke-Petersen, stated the 'Hope Valley Mission Station' was 'closed down in the war so that the RAAF could move in'. ${ }^{24}$

Despite the evacuation being mentioned in a number of books, including some based on oral history, little research appears to have been done on the reasons for the evacuation or on the key figures involved. ${ }^{25}$ The origins of the removal order, and the extent of Australian or American involvement, have remained unexplored until now. Research has conclusively established that the evacuation of all Aboriginal people at Cape Bedford was recommended by Australian military intelligence officers, approved by the Queensland government and paid for by the Commonwealth government. There was, it seems, little or no documented American involvement in the event.

19 Haviland 1997: 150; Pearson 1998: 167.

20 Queensland Government Gazette, (1934) Volume 143, no 152: 1520-1521; Rigsby 1997: 8.

21 McIvor 2010: 74-79.

22 McIvor 2010: 74.

23 McIvor 2010: 74.

24 Townsend 1983: 204.

25 Kidd 1997: 163; Donovan 2002: 137-138; Ganter 2006: 215; Evans 2007: 193. 


\section{The fear of Japanese invasion}

Many Australians were convinced that Japan intended to invade Australia during the Second World War, and was only prevented from achieving this by determined military action in New Guinea and the Coral Sea. ${ }^{26}$ Despite recent research which conclusively proves Japanese operations were intended to prevent offensive actions from Australia and not to facilitate invasion, many Australians apparently still believe this to be a verifiable historical truth. ${ }^{27}$ These continuing popular misunderstandings are probably related to the longstanding anxieties, easily and often inflamed by media or politicians, which many Australians experience about the possibility of Asian invasion by boat. ${ }^{28}$ Invasion scares are readily located in Commonwealth and State records, and have been well documented by Australian historians. ${ }^{29}$ For example, in 1923, the Investigation Branch of the Commonwealth Attorney-General's Department wrote to the Queensland government:

The Naval Intelligence Officer has reported to me that his Department has received information that "thousands of Japanese are now living on and near the coast of the Gulf (Carpentaria). There are at least three fully self-contained villages on the coast and what supplies are not grown locally they obtain from Japan". ${ }^{30}$

Queensland police were asked to report on 'this rumour', but 'patrols were not necessary'. Similarly, in 1934, the Courier Mail chartered an aeroplane to search (unsuccessfully) for a 'Mystery Japanese Sampan' supposed to be carrying 'Many Rifles' near Dunk Island. ${ }^{31}$ In early 1943, a Japanese landing 'scare' at the Gulf of Carpentaria caused many residents to rapidly evacuate the district. ${ }^{32}$

Jacqui Murray's work gives us a good insight into the misunderstanding that most Australians had of East Asia during the 1930s. ${ }^{33}$ As she showed, despite occasional fears among senior politicians and the media, many Australians were ignorant about circumstances in East Asia and often dismissed Japan as 'a nation of little import'. Murray notes 'there was very little news of Japan in the first six months of 1940' as the Australian Government tried to suppress any news that might be 'in any way provocative to Japan'. ${ }^{34}$ Augustine Meaher IV concludes that Australians were indifferent to the threat of invasion, 'preoccupied with domestic matters' ${ }^{35}$ However, Pam Oliver argues that relations between Australia

26 Frei 1991: 160-161; Johnston 2006: 11; Meaher 2010: xxviii.

27 Powell 2007: 97.

28 Stanley 2008: 25.

29 Horner 1988.

30 Commonwealth Investigation Branch to Home Secretary, 8 June 1923, QSA, A/44700, letter 6511 of 1923.

31 Harbours and Marine, April 1934, QSA, HAR/69; Courier Mail, 22 March 1934, 7 April 1934, 9 April 1934.

32 Stanley 2008: 129.

33 Murray 2004.

34 Murray 2004: 215-216.

35 Meaher 2010: 119. 
and Japan, until 1937, were mainly friendly. ${ }^{36}$ It seems that media censorship, a blind faith in 'superior' British firepower and little interest in public affairs generally combined to lull Australians into widespread indifference about Japanese intentions and capabilities.

This attitude was shared by British leaders. In July 1941, Churchill wrote to the Secretary for Foreign Affairs and the Armed Forces: 'I do not consider a war between Britain and Japan is likely at the present time' ${ }^{37}$ Newspaper coverage until December 1941 was overwhelmingly focused on Europe, with German advances making daily headlines in Australia. The sudden outbreak of war in the Pacific brought 'confusion, panic and recriminations'.$^{38}$ Authorities in Canberra announced 'This is a total war. We are all in it together. Combatants and civilians must all play their part'. ${ }^{39}$

Although some politicians and many of the public were apparently not aware of the possibility of war in the Pacific, senior British and Australian military officers certainly were. Records show that discussions between the Queensland and Commonwealth governments concerning war preparations had begun in 1939, when several North Queensland airfields were listed as 'required for defence purposes'. An Inland Defence Road, linking Brisbane with Cairns, was approved. Cooktown's existing aerodrome was initially listed as third in priority after the airstrip on Horn Island, near Thursday Island, and Coen, but soon elevated to second, and $£ 5000$ was allocated to improve the town's airfield. ${ }^{40} \mathrm{~A}$ contract for the reconstruction of the Cooktown aerodrome was approved and the Cooktown Rifle Club provided a volunteer 'Vulnerable Point' guard at the aerodrome from June 1939.

State Premiers met with federal government officials in Canberra during March 1939 to discuss co-operation between the states and the Commonwealth during wartime. One of the first items on the agenda was internal security, which included 'special arrangements' and measures 'as necessary' to control potential enemy agents. ${ }^{41} \mathrm{Co}$-ordinated responses, including 'the control and internment of hostile persons or persons of hostile association', and 'the protection of vulnerable points', were agreed:

The control of hostile persons or persons of hostile association also involves their constant observation and their arrest when required. ${ }^{42}$

36 Oliver 2010: 249.

37 Ministry of Defence (NAVY) 1995, War With Japan Volume 1: Background to the War, HMSO, London: 26-27.

38 Murray 2004: 238.

39 Department of Home Security to Department of Army, December 1941, National Archives of Australia [henceforth NAA], MP 508/1, 82/713/48.

40 Civil Aviation Department to Main Roads Commission, 7 June 1939, and Air Board to Main Roads Commission, 26 July 1939, QSA, A/6467.

41 War Cabinet Minute, 4 February 1942, NAA, A1196, 15/501/239.

42 War Cabinet Minute, 4 February 1942, QSA, QS 1043/1, 151, Part 3. 
These National Security regulations gave authorities the power to remove and restrain, without formal charges, justification or right of appeal, any group or individual perceived as a threat to Australia.

In late 1940, a defence conference was held in Singapore to discuss Japanese expansion in Indochina and Siam (Thailand). Intelligence officers noted:

One unusual condition prevailed which would facilitate landing operations by the Japanese. This was Japanese motor fishing vessels capable of towing four or five large sampans, which could transport up to 1,000 or more troops with stores and light guns. The passage of expeditions could not be opposed by surface vessels, for the Japanese would make use of little known and extremely shallow passages in which they could escape observation unless a constant patrol by lightdraft craft were maintained. ${ }^{43}$

Concerns about innovative Japanese tactics were a constant undercurrent of what became known as 'The War in the Pacific': 'Possible invasion of the coast would have to be with shallow draught craft, such as sampans', claimed one newspaper correspondent. ${ }^{44}$ Soon after, the Commonwealth Director of Military Operations and Intelligence prepared a 'Report on Queensland Guarding Arrangements (including Cooktown Aerodrome)', which stated there was 'no real threat to the aerodrome' and he recommended the military guard be withdrawn. ${ }^{45}$ Six months later, the army's Northern Command recommendation that the guard be retained revealed the aerodrome's importance. ${ }^{46}$

Towards the end of 1941, anxiety about Japanese intentions steadily increased. Ned Hanlon, Queensland's Minister for Health and Home Affairs, wrote to Premier Forgan Smith, noting there were 26 towns along 2000 miles of coastline in Queensland 'of considerable strategical importance to Australia', all of which were 'particularly easy targets for enemy aircraft and other hostile enemy action by sea' ${ }^{47}$ Plans were made for the orderly evacuation of civilians from Northern Australia. Queensland's Commissioner of Police wrote to all his officers, informing them: 'You are advised that the time is fast approaching when the question of compulsory evacuation of various classes of civilian population in the coastal belt of Queensland will definitely have to be considered'. ${ }^{48}$

Rail passes were issued to civilians and petrol stockpiles 'for evacuation purposes' were established at Queensland police stations. ${ }^{49}$ One secret War Cabinet minute stated evacuation might be undertaken from areas 'contiguous

43 Ministry of Defence (NAVY) 1995, War With Japan Volume 1: Background to the War, HMSO, London: 26.

44 'North must be ready for scorched earth', Courier Mail, 21 February 1942: 5.

45 Director of Military Operations and Intelligence to Department of Defence, 16 November 1940, NAA, MP 729/6, 25/401/238.

46 Department of Defence to Department of Air, 11 June 1941, NAA, MP 729/6, 25/401/238.

47 Hanlon to Premier Forgan Smith, 4 September 1941, QSA, A/6478, letter 7820 of 1941.

48 Commissioner of Police to all police, 26 January 1942, QSA, A/73478, 279 M4.

49 McIntyre 1992: 15-17. 
to possible targets', and noted 'special arrangements will be necessary for maintenance of security'. ${ }^{50}$ National Security Emergency Control Regulations were proclaimed for North Queensland. Regulation 32 covered 'the evacuation of civilians, animals and things', while Regulations 54 and 55 gave the military 'power to take possession of land' and authority to 'take over land and buildings for service use' ${ }^{51}$

The War Cabinet ordered compulsory evacuations of women and children from Darwin in December 1941, although nurses and missionaries 'who may wish to remain' were exempt. ${ }^{52}$ Voluntary evacuations began in North Queensland during early 1942, soon after Japanese forces attacked New Guinea and the Solomon Islands. ${ }^{53}$ Rabaul fell at the end of January, and Japanese aircraft using the town's airfield began operations against Allied forces in the Southwest Pacific.

However, a meeting of State Premiers and the federal government in February 1942 decided that 'undue emphasis should not be placed upon evacuation measures as this would be detrimental to the morale and to the maintenance of essential production'. ${ }^{54}$ The arrival of advance units of American forces in February 1942, two months after the Japanese raid on Pearl Harbor, left Australians in no doubt about the proximity of the enemy. ${ }^{55}$

Parties of 'coloured' evacuees and missionaries from New Guinea, the Torres Strait and other islands in the Southwest Pacific arrived by aircraft, launch and steamer at Cairns and Townsville. Regina Ganter has noted how 'colour-coded evacuations' began across North Australia, with white women and children moved before Indigenous and Asian people. ${ }^{56}$ Cooktown was one of the first towns evacuated in North Queensland. There was, as previously noted, no road connection between Cooktown and the remainder of North Queensland at the time, so speedy evacuation was difficult. The civilian population began to panic:

All available accommodation outward has been booked up for some time ahead. The weekly launch carried as many as possible on Friday last. It would appear that the exodus is restricted to the amount of accommodation available on outward trains from Cairns. Most of the people leaving the town have departed hurriedly leaving furniture and most of their other household effects. ${ }^{57}$

50 War Cabinet Minute, 4 February 1942, NAA, A 1196, 15/501/239.

51 Army HQ to Civilian Evacuation Service, 6 December 1942, NAA, SP1008/1, 469/3/41.

52 Civilian Evacuation Service to Premier's Department, December 1941, QSA, A/6472, letter 10454 of 1941; Alcorta 1991: 19; Somerville 2011: 3.

53 'Voluntary evacuation for whole coastal area', Courier Mail, 30 January 1942; 'Population transfer: move from North Queensland', Sydney Morning Herald, 13 February 1942: 7; Moles 2005: 12-17.

54 War Cabinet Minute, 4 February 1942, NAA, CP80/1, Bundle 1/S97.

55 Potts and Potts 1985: 26.

56 Ganter 2006: 216.

57 'Cooktown notes', Townsville Bulletin, 4 February 1942: 2. 
Hundreds of women, children and elderly residents left coastal centres, catching trains south from Cairns to Brisbane and inland to the Atherton Tableland. Evacuation from Cooktown continued, as 'many of the workers and their families' left the town: 'Last week the launch was again filled and plane services were heavily taxed. The few women and children remaining are expected to be going shortly' ${ }^{58}$

When Darwin was first bombed on 19 February 1942, some newspapers speculated that this might be the first phase of a Japanese invasion:

The Darwin bombings may or may not have been the precursors to an attempted landing in force in the Northern Territory, but there are many strategic reasons why a sharp attack on some part of the Queensland coast, followed by an effort to secure a permanent base, may be expected. A bombing and supply base in a North Queensland port would link up with the New Guinea enemy bases. ${ }^{59}$

'The battle for North Queensland', exclaimed the Cairns Post, 'may open at any moment'. On 23 February, the military took 'general control' of the northern part of the Northern Territory. ${ }^{60}$

Newspapers stopped publishing news from Cooktown in early March 1942, which meant that important events in the district were largely unnoticed by other Australians. According to the final 'Cooktown Notes' in the Cairns Post, 'The proximity of the Japanese is the uppermost thought in each mind'. Potential 'Japanese sympathisers' were 'removed':

Quite a few people have been rounded up during the last few weeks, the cause of their internment being known to the authorities. The weekly launch carried away a big complement of passengers. Possibly only about 15 females remain, with a sprinkling of children. ${ }^{61}$

It is unclear who these 'potential collaborators' were, although there were a number of 'alien' families in the district, and this may refer to some of them. There was little or no public debate about the legality or appropriateness of these wartime imprisonments. Internees were taken to Enoggera in Brisbane, and later further south to Tatura in Victoria.

Plans for a 'Scorched Earth Policy' in Northern Australia were openly and widely discussed. ${ }^{62}$ News about the proximity of Japanese operational bases in New Guinea prompted concern. 'The Japanese will try to get aerodromes and footholds on the coastal area, from which they could bomb the centres of population. Australia must avoid that at all hazards and keep the Japanese

58 'Cooktown notes', Townsville Bulletin, 14 February 1942: 2.

59 Cairns Post, 23 February 1942: 5.

60 Powell 2007: 99.

61 'Cooktown notes', Cairns Post, 4 March 1942: 3.

62 'Scorched earth plan for Army', Courier Mail, 3 February 1942: 1; 'North must be ready for scorched earth', Courier Mail, 21 February 1942: 5. 
aeroplanes far from the cities and towns' said the Courier Mail. ${ }^{63}$ Six days later, on 16 March 1942, news of the first air raid on Thursday Island emerged. ${ }^{64}$ German propaganda broadcasts claimed New Guinea would be taken in 'days or hours': 'After the occupation of New Guinea, enemy bases in North Australia, Cooktown, Townsville or Thursday Island will be entirely at Japan's mercy' ${ }^{6}{ }^{6}$ HV Evatt, the Australian Minister for External Affairs cabled the Australian High Commissioner in London on 26 March stating 'I believe very short period ahead of us will determine whether our country will be overrun', adding a 'full scale invasion' was 'likely'. ${ }^{66}$

In April, one month before the Cape Bedford Mission evacuation, senior army officers prepared for the worst, including the 'total evacuation of Brisbane' if necessary: 'evacuation plans should be made for the area of the whole coast of Queensland, all of which must be considered as open to enemy operations' ${ }^{67}$

\section{The fear that Aboriginal people would assist a Japanese invasion}

Some Australians thought Aboriginal people might collaborate with the Japanese army. ${ }^{68}$ Furthermore, Lutheran missions had been under suspicion in the First World War:

The missions under review have unquestionably been active and dangerous enemy outposts. Whatever good they may have done or whatever the value of their religious efforts, there can be no question of the extremely valuable services they have rendered to Germany both politically and commercially. ${ }^{69}$

By 1942, some military intelligence officers obviously connected Japanese knowledge of Australian coastal waters with previous interactions between Aboriginal people and Japanese fishing vessel crews to conclude that major potential national security threats existed in Australia's tropical north. This subject, and the responses of European Australians, is discussed by Noel Pearson, by Robert Hall (in his seminal work on Aboriginal people during the Second World War) and by Kay Saunders. ${ }^{70}$ Hall states the Services 'particularly the Army which was responsible for internal security, suspected them of favouring a Japanese victory' ${ }^{71}$

63 'Aerodromes on coast must be held', Courier Mail, 10 March 1942: 3.

64 No Japanese attacks took place at Thursday Island, but eight raids were made on neighbouring Horn Island; see Dennis et al 2008: 290.

65 'Japanese bombs on Thursday Island', Townsville Bulletin, 16 March 1842: 3.

66 Hudson and Stokes 1982: 683.

67 Army HQ to Army GHQ, 2 April 1942, NAA, MP 508/1, 82/713/48.

68 Stanley 2008: 145.

69 Pro-German Missions Report, 1919, NAA, A367, C612: 2, cited in Pearson 1998: 211.

70 Saunders 1995; Hall 1997; Pearson 1998: 204-210.

71 Hall 1997: 113. 
As several historians have noted, A Naylor, the former Superintendent of Yarrabah Mission near Cairns, wrote to the military forces at Townsville in late January 1942 drawing attention to 'a possible menace to the people resident in North Queensland':

[I]n particular, in reference to the Aboriginal population spread out along the Eastern Seaboard from Cape York southwards. There are several Aboriginal reserves including the Yarrabah Mission Station near Cairns, and if not under Military control it is possible for these aboriginals to convey information by signalling in native fashion by fire, smoke and other means, to the invader. ${ }^{72}$

The letter, duly forwarded to the army's Northern Command at Townsville, was annotated 'Former Yarrabah superintendent Campbell reports that the matter of smoke signalling is not possible on a workable scale' ${ }^{73}$ However:

The Cape Bedford mission is conducted by the Lutheran Church and the superintendent is believed to be a German. This may a source of dissemination of information to the enemy. If this is so, it would appear to be highly desirable to exercise some supervision on this place, if this is not already being done. ${ }^{74}$

Military intelligence was not accurate. By the beginning of the Second World War, Schwarz, a naturalised Australian, had completely severed all ties with his German family. ${ }^{75}$

Japanese knowledge of Australia was probably reasonably detailed as a result of pre-war activities. In 1937, four articles on the pearling industry by popular author Ion Idriess, titled 'Problems of the North', appeared in Brisbane's Courier Mail. ${ }^{76}$ The final item contained a warning to Australians:

Australian pearling vessels manned by Japanese and other foreign crews can land lawfully on our coasts whenever they are in need of wood or water. That these are found wherever there is a camp of aborigines is easily understood..$^{77}$

72 Former superintendent Naylor to Commandant of Military Forces at Townsville, 28 January 1942, AWM 60, 66/1/88.

73 The annotations on Naylor's letter were made by the 'Brigadier Commanding the 11th Infantry Brigade' at Townsville.

74 Naylor to Commandant of Military Forces at Townsville, 28 January 1942, AWM 60, 66/1/88.

75 See 'Schwarz, George Heinrich', German Missionaries in Queensland website, <http:// missionaries.griffith.edu.au/biography/schwarz-georg-heinrich>

76 Idriess 1937a, b, c, d, 'Pearl shelling industry may be lost', Courier Mail, 7 January 1937; 'Quiet, workmanlike, and efficient', Courier Mail, 9 January 1937; 'Legitimate competition of Japanese for shell', Courier Mail, 11 January 1937; 'It is dangerous to leave our backyard unfenced', Courier Mail, 12 January 1937.

77 Idriess 1937d, 'It is dangerous to leave our backyard unfenced: tropic seas a great industrial asset', Courier Mail, 12 January 1937. 
Idriess said the Cape Melville tribe 'welcomed' the Japanese luggers and sent their women to the crews in return for trade goods. ${ }^{78}$ Pam Oliver argues there was 'little active spying' by Japanese in Australia before the war, but some members of the public thought the espionage had already been completed. ${ }^{79} \mathrm{JT}$ Woods of Toowong, who 'several years ago was in the Government service stationed at Thursday Island', wrote to the Courier Mail:

They know every inch of the Queensland coast. Thursday Island could be destroyed in a couple of hours. They would not attempt a landing there; if ever they did attempt a landing it would be lower down the coast, for they have had all the coast down as far as Mackay mapped out for years ready for this present conflict. ${ }^{80}$

Other Queenslanders offered similar advice to the authorities. Mrs Jessie Miller contributed her thoughts: 'My father used to be the superintendent of the light on Cape Melville, and during the pearlshell season the Japanese used to frequent the bay'.

Her father, she stated, told her:

On one occasion, two Japanese, who said they were officers of the Japanese Navy, in charge of luggers, told my father that they knew of passages in the reef through which they could bring naval vessels. It is an excellent landing place and has a plentiful supply of water. ${ }^{81}$

The pre-war maps compiled by Japanese navigators in Australian coastal waters were probably better than Australian charts because of their many years of pearl-shell harvesting experience. The nautical maps would, undoubtedly, have been very useful to Japanese military forces. However, it is worth noting that the Japanese maps of Cape York Peninsula and the Gulf of Carpentaria currently held in the Queensland State Archives were compiled in 1942, not before the war. ${ }^{82}$ Unfortunately there is no record of where these particular maps were found. One retired Japanese pearl diver told Regina Ganter that fishing boats were used by the Japanese navy to spy and make charts in other parts of the Southwest Pacific, so it reasonable to assume that similar activities took place off the coasts of Australia. ${ }^{83}$

Pastor LA Borgas, the Superintendent of the Seventh Day Adventist Mission at Mona Mona, near Cairns, wrote to the Director of Native Affairs at Brisbane in February asking for advice on evacuation due to the 'imminent invasion of

78 Idriess 1937c, 'Legitimate competition of Japanese for shell: difficulty of protecting native women', Courier Mail, 11 January 1937.

79 Oliver 2010: 246.

80 Courier Mail, 6 February 1942: 4.

81 Courier Mail, 12 February 1942: 4.

82 Japanese maps, 1942, QSA, SRS 4848/1/2.

83 Ganter 1992: 188-189. 
Australia by Japan' ${ }^{84} \mathrm{O}$ 'Leary replied: 'the Authorities have given no direction for compulsory evacuation of aboriginals'. He said standard air raid precautions should be provided, but:

[A]part from that no detailed plan of evacuation exists. In an extreme emergency there is of course always the possibility of an evacuation of aboriginals to the western settlement outside of Duaringa. ${ }^{85}$

The Aboriginal settlement at Woorabinda, near Duaringa and inland from Rockhampton, was seen as the best place for any wartime Indigenous evacuees from the North. However, it seems, at this stage, that authorities did not share some of the public's distrust of Aboriginal people.

Not everyone agreed with the removal, and the way in which it was conducted. After the evacuation of the Cape Bedford Mission, former Cook Shire Chairman Andrew Standfield Sampson wrote from Cooktown to Mrs Bennett at Eumundi, the daughter of missionary Schwarz, apologising for the way 'officialdom' had dealt with her family. He said:

[T]he efforts of the police (and government) would have been better directed if they had rounded up the "myall" blacks from here to Cape York whose struggle for existence is so great that their tracking instincts are highly developed and who for years at places like Barrow Point and Starcke River have been fed and given tobacco by the Jap luggers. I am told by Miss Black that these aboriginals have openly stated that the Japs told them, that the country belonged to the blacks, had been stolen from them by the whites and that "bye and bye" they (Japs) would give it back to them (the blacks) so! ${ }^{16}$

He also wrote 'What a howl there would be if some of our folk were so treated by an enemy', and added a postscript informing her 'you may make what use you like of this letter' in writing to the authorities, which she promptly did.

In late March 1942, Australian papers began publishing stories about Lutheran missionaries assisting Japanese forces in New Guinea:

Lutheran guidance of the Japanese is the acme of treachery. Now that the Lutheran traitors have openly joined the Japanese, the story of their treachery and the amazing laissez faire of the old Administration can be told. After war began they did not conceal their views. Civilians reported that native children were taught the Nazi salute, gave evidence of the use of secret radios and pointed to the elaborate aerodrome landing field

84 Superintendent Borgas to Department of Native Affairs, 11 February 1942, QSA, QS 505/1, $1 \mathrm{E} / 14$.

85 AS Sampson to Mrs Bennett, 18 May 1942, QSA, QS 505/1, 1E/14.

86 AS Sampson to Mrs Bennett, 18 May 1942, QSA, SRS 505/1/4685. 
network. Australia, in danger of a Japanese attack, must take a more realistic attitude towards its suspected aliens, whether naturalised or unnaturalised. ${ }^{87}$

A communiqué released by Prime Minister John Curtin said 'there was unconfirmed information indicating support of the enemy by German missionaries', but the newspaper reporters were already convinced, one stating 'there is definite proof that certain Lutheran missions were the centres of activity' ${ }^{88}$ Attitudes began changing quickly after this, and the evacuation of the Cape Bedford Mission soon became a military intelligence priority. Four months later, in July 1942, and long after the removal of the Cape Bedford Mission residents, some of the press was still circulating similar views:

[T]here was definite knowledge, not merely suspicion, that many German missionaries, both Lutheran and Roman Catholic, indulged in anti-British activities. There was also definite knowledge that the native followers of these German missionaries were taught anti-British sentiments. ${ }^{89}$

It seems that anxiety about 'potential sympathisers' took longer to subside in some rural Queensland districts than it did in other parts of Australia. Hall says suspicion of Lutheran missions in Australia began - well before December 1941 - when the Beagle Bay Mission in Western Australia was taken over by Army Intelligence and the German missionaries interned in $1940 .{ }^{90}$

Cape Bedford, although apparently ignored for two years, did not escape attention. As noted earlier, O'Leary wrote to the Home Secretary on 23 March 1942, three days after claims of alleged Lutheran 'treachery' first appeared in the papers, saying:

[I]t is considered by Military Authorities that the alleged assistance rendered the Japanese Army in New Guinea by German missionaries could be repeated at Cape Bedford Mission, and the Authorities are not prepared to take the risk of such. ${ }^{11}$

O'Leary's report predated official correspondence, which may suggest he had been holding informal meetings with military authorities. Brisbane was just a big country town, and casual encounters between top public servants and military officers were quite possible, and almost unavoidable. Army Headquarters in Brisbane wired Melbourne urgently recommending detention orders for the Cape Bedford missionaries, George Schwarz and Victor Behrendorff, three days

87 'Traitors leading Japanese', Courier Mail, 20 March 1942: 1; 'Lutheran traitors: guides for Japanese soldiers', West Australian, 20 March 1942: 5.

88 'Japanese advancing in north New Guinea: treacherous aid from Lutheran missions', Canberra Times, 21 March 1942: 1; 'Nazi centres revealed: Fifth Column in New Guinea', Sydney Morning Herald, 21 March 1942: 10.

89 'Nazis' hand in New Guinea', Rockhampton Morning Bulletin, 31 July 1942: 6.

90 Hall 1997: 114.

91 O'Leary to Home Secretary, 23 March 1942, QSA, SRS 505/1/4685, letter 3964 of 1942. 
after O'Leary's report, on 26 March 1942. ${ }^{92}$ Four days afterwards, on 30 March 1942, the Director of Military Security at Brisbane wrote to the Director-General of Military Security at Canberra, noting 'German missionaries were assisting the Japanese in New Guinea':

Cape Bedford with ten German missionaries and 300 Blacks is ideally suited for use by the Japanese and if they have persons in that area who are prepared to assist them, the danger becomes greater. ${ }^{93}$

He recommended the mission be closed and the removal of all inmates to Barambah (now known as Cherbourg) Aboriginal Settlement in southern Queensland, stating senior police and the Chief Protector of Aboriginals (JW Bleakley) had 'fully agreed' with the action.

The Director-General of Security wrote to the Minister for the Army (Frank Forde) regarding the Cape Bedford Mission:

$[\mathrm{T}]$ here is a good reason to fear that there may be some fifth-column activity there as a result of the presence of about 10 missionaries who are probably all of enemy extraction. It is desired to know whether or not the position at Cape Bedford is regarded from the point of view of Army as a dangerous one and if so and I am informed I will take steps at once to ensure that the whole of the 300 Aborigines are removed to Barambah. ${ }^{94}$

'Action', he said, 'should be taken at once'. The file was annotated:

The information is sparing and the source of report not disclosed. The national status of the missionaries is not shown. The strategic and practical value of the locality as an enemy base is not supported by data. Notwithstanding this, on the data disclosed I consider there is sufficient to warrant precaution if no protecting force is stationed there, the real point is whether the missionaries and natives could and would assist the enemy as guides on the mainland. It seems reasonable to assume that they may do so. ${ }^{95}$

Again, military intelligence was severely lacking. The origins of the claim there were ten missionaries, 'who are probably all of enemy extraction', at Cape Bedford, is unknown. One memo between two army officers, dated 7 April, stated a German missionary at Cape Bedford was 'suspected to have been in direct contact with Japanese'. Fear of Aboriginal people assisting Japanese invaders was apparent: 'This station is in a most inaccessible spot and strong suspicions that Japs have already been ashore' ${ }^{96}$

92 Army HQ to Army GHQ, 26 March 1942, NAA, MP 742/1, 1/6/204.

93 Director of Military Security to Director-General of Military Security, 30 March 1942, NAA, MP $742 / 1,1 / 6 / 204$.

94 Director of Military Security to Director-General of Military Security, 30 March 1942, NAA, MP $742 / 1,1 / 6 / 204$.

95 Director-General of Military Security to Minister for Army, 31 March 1942, NAA, MP 742/1, $1 / 6 / 204$.

96 Captain Graham to Major Wilkinson, 7 April 1942, NAA, MP 742/1, 1/6/204. 
The officer in charge of the Cooktown police station was 'advised in strictest confidence' that the army and the government were carefully considering what to do with the mission. ${ }^{97}$

Close states the army did not conduct any form of judicial inquiry into these allegations of 'treasonous activity'. ${ }^{98}$ Under National Security regulations, hearings were not necessary. Detention orders for missionaries Schwarz and Behrendorff were signed by Forde (the Minister for Army) on 17 April. Schwarz wrote to the Department of Native Affairs on 27 April advising 'a man of the local Air Force arrived here and informed me that he had orders from his commanding officer to take immediate delivery of my car' ${ }^{\prime 9}{ }^{99}$ On 29 April the army wrote to Forde urging the 'disbanding' of the mission based on the report from the Director-General of Security. '[T]here is danger of tremendous harm being done if the missionaries should decide to give assistance to the enemy. This danger is far too great to permit of our taking any risks' ${ }^{\prime 100}$ But was this, as Roy McIvor says, the only reason for the evacuation of the Cape Bedford Mission?

\section{The mission aerodrome}

Cooktown's first civilian airfield, established in 1937, was located on salt pans west of the town at a place known as 'The Four Mile'. Until that time, aircraft had been landing on the town's racecourse. ${ }^{101}$ The new 'aerodrome' was surrounded by earth banks designed to prevent inundation during high tides, but the field was always damp and planes often became bogged. Nearby hills also made aircraft operations difficult and dangerous.

After war began, additional buildings were erected to accommodate advance units of the Royal Australian Air Force (RAAF) and military aircraft began operating from the airfield in late 1940. In 1941, an officer reported twice on the existing facilities at Cooktown, noting on each occasion the absence of a water supply. ${ }^{102}$ Improvements, as previously noted, were carried out, and the airfield (now known as 'Advanced Operational Base Cooktown') was handed over to the RAAF in early 1942. However, the problems of drainage and the shortness of the runways meant the search for an alternative site continued in earnest.

At the same time that the decision was made to 'disband' the Cape Bedford Mission, a report appeared stating land at 'The Eight Mile' on the Endeavour River, owned by missionary Schwarz, would be the most suitable site for a new military airfield. ${ }^{103}$ Larger events also affected developments at Cooktown:

97 Department of Native Affairs to Protector of Aboriginals at Cooktown, 16 April 1942, QSA, SRS $505 / 1 / 4685$.

98 Close 2009: 53.

99 Schwarz to Department of Native Affairs, 27 April 1942, QSA, SRS 505/1/4685.

100 Department of Army to Minister for Army, 29 April 1942, NAA, MP 742/1, 1/6/204.

101 Ryle 2000: 314.

102 Royal Australian Air Force, NAA, B 595/120, 65/97/16, Pt 3; Sinclair 2005: 12.

103 Main Roads Commission 1949: 25; Sinclair 2005: 25. 
during the first week of May, Allied forces won the Battle of the Coral Sea, now recognised as the first naval battle in which opposing vessels never sighted each other. Japanese convoys heading for Port Moresby were recalled and invasion was stalled. Apart from submarines, Japanese naval ships never came so far south again. Although this was an inconclusive battle, it was significant because aircraft and aircraft carriers had replaced battleships for the first time in history. Airfields were now critical sites, and military priorities took precedence.

Fear of Aboriginal 'fifth-column' activities remained. On 6 May, RAAF pilots reported 'smoke signals given from the Cape Bedford mission on arrival and departure of planes' at Cooktown. ${ }^{104}$ Senior army officers in Brisbane reported 'Execution of warrants held over pending decision to remove all natives to Barambah to prevent them going bush and making contacts for Japanese' and 'The removal of the aborigines from the Mission is a matter for the Queensland Government'. Brisbane's approval was advised on 10 May: 'Queensland state authorities fully prepared to arrange removal of the aborigines from Cape Bedford' ${ }^{105}$ Although the army had first recommended the mission's evacuation, it was clearly understood that the removal process was a State matter. Military authorities recognised that the State would remove the Aboriginal people while the Commonwealth would provide the funding for the evacuation and proceed with the internment of the missionaries. ${ }^{106}$

Perhaps there was awareness that the removal of the missionaries might have created confusion amongst the Aboriginal people on the Cape Bedford Mission. It is also possible that the authorities were aware of the urgent need to acquire land for the new RAAF airfield, namely the land on the Endeavour River currently owned by missionary Schwarz. Regardless of the real reasons, the story that emerged was that the Cape Bedford people had been removed because of the fear that their 'contamination' by German missionaries might make them more amenable to assisting a Japanese invasion. It is unclear when the Lutheran Mission Board in Adelaide was advised of the evacuation.

On 10 May, the same day that $\mathrm{O}^{\prime}$ Leary advised the evacuation had been approved, a Main Roads Commission memo was sent to the Allied Works Council, the Commonwealth's peak body for defence infrastructure. Noting the current work on the existing airfield, the memo stated:

The position is that Cooktown's field is out of favour of the operational men. The general scheme includes an airfield at or near Laura. However, a suitable site for a strip was located just across the Endeavour River on the McIvor River Road. ${ }^{107}$

\footnotetext{
104 Army HQ to Army GHQ, 6 May 1942, NAA, MP 742/1, 1/6/ 204.

105 Army HQ to Army GHQ, 9 May 1942, NAA, MP 742/1, 1/6/204.

106 Army HQ to Army GHQ, 10 May 1942, NAA, MP 742/1, 1/6/204.

107 Main Roads Commission to Allied Works Council, 10 May 1942, QSA, 18925 Defence Roadworks Files, 22A-1-85.
} 
The memo's author recommended approval for the proposed mission airstrip. Two weeks later a decision had clearly been made: an urgent memo from 'M.R.C. Base Section No 2 to the Officer in Charge of U.S. Works' stated: 'Rush Priority: Cooktown Endeavour River Site, approximately 3 miles upstream from Cooktown Aerodrome; clear and level 7,000 runway' ${ }^{108}$ Work on a military strip at Mareeba, south of Cooktown, began on 12 May, suggesting that both construction tasks were approved at the same time. ${ }^{109}$

A progress report in July 1942 advised 95 per cent of earthworks had been completed and 30 per cent of the airstrip constructed. ${ }^{110}$ Between 50 and 100 men were employed on this job for the next 18 months. A company of Australian soldiers was assigned to guard the 'Mission Aerodrome'. ${ }^{111}$ The Main Roads Commission reported on the 'replacement strip' for the existing Cooktown 'drome' at the end of 1942, noting 'Emphasis is placed on the unsuitability of this aerodrome for RAAF purposes and an economic analysis justifies its abandonment'. ${ }^{112}$ An attached report said Cooktown Aerodrome was only used for the refuelling of transient freight and combat aircraft, and the Endeavour River strip was 'primarily designed for U.S. Army bomber operation'.

Work on the old airfield had been abandoned to 'permit construction of the U.S. Army Aerodrome', and 'it is now proposed that fighter squadrons should be based on this aerodrome'. This was the first reference to American involvement in the project. The new airfield, now known as the 'Cooktown Mission Strip' was completed, at a cost of $£ 98,000$, in early $1943 .{ }^{113}$ After the war, civilian aircraft continued to operate from Cooktown's 'old' airfield until a cyclone in 1949 damaged the tidal barriers and prevented further aircraft use. ${ }^{114}$ The 'Cooktown Mission Strip' then became the town's official airport and remains so to this day.

\section{The evacuation}

During the first week of May, Army Headquarters at Brisbane wrote to Army GHQ at Melbourne asking 'Could decision be given immediately re transfer of mission natives on arrest of principals' ${ }^{115} \mathrm{O}$ ' Leary ordered Cecil Foote, the Acting Superintendent at the Palm Island Aboriginal Settlement, near Townsville, to proceed to Cairns. ${ }^{116}$ Foote, three military guards and police would carry out

108 Main Roads Commission Base Works to Works Department, 25 May 1942, QSA, 18925 Defence Roadworks Files, 22A-1-85.

109 Waters 2003: 10.

110 Main Roads Commission to Allied Works Council, 11 July 1942, QSA, 18925 Defence Roadworks Files, 22A-1-85.

111 September 1942, AWM, AWM 54, 243/6/102.

112 Engineer Bettridge at Cooktown to District Engineer at Townsville, 30 September 1942, QSA, 18925 Defence Roadworks Files, 22A-1-85.

113 Main Roads Commission to Allied Works Council, 16 April 1943, QSA, 18925 Defence Roadworks Files, 22A-1-85.

114 Ryle 2000: 372.

115 Army HQ to Army GHQ, 6 May 1942, NAA, MP 742/1, 1/6/204.

116 Department of Native Affairs to Superintendent Foote, 10 May 1942, QSA, SRS 505/1/4685. 
the evacuation at Cape Bedford; other soldiers would help 'guard' the evacuees at Cairns. ${ }^{117}$ This detail - about the forces that carried out the evacuation - is the second reason for this research. Differing accounts have emerged, including widely-believed claims that armed soldiers conducted the removal.

Former missionary Howard J Pohlner says the evacuation was carried out by 'half a dozen trucks, with local drivers, accompanied by armed American soldiers' ${ }^{118}$ Pohlner's interpretation of events, and of those involved, was apparently based on the recollections of Schwarz, 'a Cooktown identity' named Charlie Sanders, and one Aboriginal informant, George Bowen. According to historian Robert Hall, 'the Army' and a 'convoy of trucks' removed everybody from Cape Bedford on 17 May. ${ }^{119}$ He gave no details of the forces involved, but resident Victor Cobus recalled 'armed American soldiers' loading the mission people on to trucks, 'without even the chance to get our things' ${ }^{120}$ Linguist John Haviland and resident Roger Hart said 'soldiers' and 'military police' were involved. ${ }^{121}$ Noel Pearson quotes one informant who stated 'there were about nine Army trucks that day', and although soldiers were mentioned, 'the Authorities' sent 'nineteen policeman and police Main Boss' to stop any attempt to 'run away'. ${ }^{122}$

Ros Kidd states the relocation, which she described as 'appallingly bungled', was conducted by military and police. ${ }^{123}$ Cairns writer Vera Bradley quotes retired policeman Tom Griinke, who said about 12 police and three Military Intelligence officers removed the mission. ${ }^{124}$ No weapons are mentioned. Local historian Don Sinclair includes extracts from both Pohlner's and Bradley's books. ${ }^{125}$ Most recently, Roy McIvor described the men who moved them as 'soldiers or policemen'. ${ }^{126}$ Records reveal the truth.

Plans for the eventual destination and transport remained fluid until the last minute. On 11 May, the power to requisition a boat for the voyage from Cooktown to Cairns was granted to local naval authorities under National Security general regulations. At first, launches normally used to carry tourists were to be provided by Hayles, a Townsville ferry and launch hire company. However Foote sent a telegram from Cairns to Brisbane on 12 May: 'Hayles only allowed carry fiftyfive each trip hence reason insistence remove full party one time ${ }^{\prime}{ }^{127}$ On the same day he reported: '12 police were going to Cooktown tomorrow and will assist there'. His next statement was revealing:

117 Foote reported a police sergeant, 11 constables and three military intelligence officers went with him. CH Sanders wrote from Cooktown, saying 'Police headed by the Sergeant of Police at Cooktown and Cairns arrived in Lorries, Cars \& Armed Guard', Sanders to Department of Native Affairs, 25 May 1942, QSA, SRS 505/1/4685.

118 Pohlner 1986: 112.

119 Hall 1997: 116.

120 Cobus and Cobus 1994: 11.

121 Haviland and Hart 1998: 133.

122 Pearson 1998: 212-213.

123 Kidd 1997: 163.

124 Bradley 2003: 113-114.

125 Sinclair 2005: 17-19.

126 McIvor 2010: 74.

127 Foote to Department of Native Affairs, 12 May 1942, QSA, SRS 505/1/4685. 
I understand they have certain instructions regarding certain people there and that is the main reason for their visit and that they will leave the boat again at Cairns. ${ }^{128}$

This suggests that it was the missionaries who were the military's main concern, not the Aboriginal people, which focuses attention on the land owned by Schwarz. Once he was interned, compulsory acquisition of the proposed airfield site would be a mere formality. Behrendorff, who resigned from the mission six weeks earlier to enlist in the Australian armed forces, was arrested on the same day at Bundaberg, in south-east Queensland, and interned. ${ }^{129}$ As previously noted, Schwarz's car was confiscated in late April, suggesting he was probably aware of what was about to happen. ${ }^{130}$ The 'eight' other alleged missionaries, listed in military intelligence reports, disappeared from records. They never existed.

As noted, one police officer's recollection of events has been published. According to Constable Tom Griinke from Innisfail, 'Sub Inspector Roache from Cairns was in charge of a party of ten, called in from Cairns and Innisfail police stations, to assist Sergeant Teichman and Constable Jack Peters (both stationed at Cooktown) with the evacuation'. ${ }^{131}$ Griinke said they travelled to Cooktown on Hayles' launch, and on the morning of 17 May 'we were driven to the Mission in a convoy of army trucks and helped the natives pack their few belongings'. Firearms, which were not routinely carried by police, were never mentioned. Foote reported he organised one truck from the aerodrome, five from the Department of Main Roads and three local trucks. ${ }^{132}$ Only one appeared to be a military vehicle, and there is no record of any American military involvement in the removal exercise. Presumably each of these hired trucks came with a driver. In April 1944, an invoice for $£ 46 / 11 / 8$ 'due for hire of trucks used in the transport of aboriginals from mission aerodrome to Cooktown for transfer south' was sent to the army by the Queensland Main Roads Commission. ${ }^{133}$ According to Foote:

The whole party and Sergeant Teichman of Cooktown set out for the Mission, arriving at the part where Mr. Schwarz lived about 9am. We then went to the 18 Mile where most of the natives lived in charge of Mr. Behrendorff. On arrival we found all houses closed up and no natives there. Runners were sent out and they were located along the river and picked up. ${ }^{134}$

The residents had already left for their own safety. According to Victor Cobus, Schwarz moved the residents from the mission because of the threat of invasion. ${ }^{135}$ Roy McIvor tells how families, including the Pearsons, moved from

\footnotetext{
128 Foote to Department of Native Affairs, 12 May 1942, QSA, SRS 505/1/4685.

129 Commonwealth Investigation Service, NAA, A 1533, 1957/3354.

130 Schwarz to Department of Native Affairs, 27 April 1942, QSA, SRS 505/1/4685.

131 Bradley 2003: 113-114.

132 Foote to Department of Native Affairs, 29 May 1942, QSA, SRS 505/1/4685.

133 Main Roads Commission to Department of the Army, April 1944, NAA, MP 742/1, 1/6/204.

134 Foote to Department of Native Affairs, 29 May 1942, QSA, SRS 505/1/4685.

135 Cobus and Cobus 1994: 11.
} 
the mission to humpies by the river. ${ }^{136}$ Despite clear instructions for Foote to ensure that sufficient supplies were provided, and all 'personal effects' gathered, one eye witness claimed 'they were not given time to collect their belongings', particularly carpentry and building tools. ${ }^{137}$ No details about the evacuation or ultimate destination were given to the residents, who did not know whether their removal was to be long-term or permanent.

When applications for compensation were made in 1943, the army claimed 'the only items left in the huts after the evacuation were just the few necessities and curios that could be expected to be found in an Aboriginal's hut'. ${ }^{138}$ When the army finally sent a compensatory payment to Lutheran authorities in 1945, the Department of Native Affairs wrote back, stating:

At the time of the evacuation of the Cape Bedford tribe from this area, which was carried out at very short notice and without warning, much of the personal effects of the natives was abandoned and lost. ${ }^{139}$

Several months later, Foote was called on to explain why the Cape Bedford people were not properly fed during the evacuation. He offered an explanation:

These people were brought to Cooktown during the afternoon and night of 17 May. The boat on which they were to leave arrived at Cooktown at about 7-30am on 18 May and left about 9am the same day remaining there only sufficiently long enough to load the people, implements, material, etc. I had brought from the Mission. ${ }^{140}$

'I naturally concluded', he said, that the people would be fed on the journey to Cairns, but as the boat was about to leave the Captain told him he 'did not intend to feed the people'. Foote said he threw two shillings to a constable on the wharf and asked him to send a telegram to Cairns asking for a meal to be ready. However, the boat arrived at Cairns before the telegram did, and the evacuees were immediately loaded on a train at the Cairns wharf. The evacuees were possibly carried south in goods or cattle wagons, but this was not uncommon in wartime Queensland. Many soldiers travelled north in the same fashion. According to one informant, 'soldiers and government agents used to walk among them on the train occasionally speaking to them in German, evidently hoping to confirm their suspicions'. ${ }^{141}$ The evacuees discovered shops and refreshment rooms were mostly closed every time the train stopped. ${ }^{142}$ Apart from three meals en route, little food was provided for two days, and they slept on the train.

137 AS Sampson to Mrs Bennett, 18 May 1942, QSA, A/58886, letter 4050 of 1942; Department of Native Affairs to Defence Hirings, 21 November 1945, QSA, SRS 505/1/4685.

138 Army Hirings to Department of Native Affairs, 18 September 1943, QSA, SRS 505/1/6B/690.

139 Department of Native Affairs to Defence Hirings, 21 November 1945, QSA, SRS 505/1/6B/690.

140 Foote to Department of Native Affairs, 30 September 1942, QSA, SRS 505/1/4685.

141 Cited in Haviland 1985: 175.

142 Pohlner 1986: 113. 


\section{The aftermath of the evacuation}

The people from Cape Bedford had lived in the warm northern tropics all their lives and nothing could have prepared them for the cold, flat country they arrived in on 20 May. Many of 254 evacuees died within six months of their arrival, and officially 33 of the Cape Bedford people passed away at Woorabinda, far from their own country. ${ }^{143}$ This figure is questionable; one letter from the Woorabinda superintendent dated March 1943 records 48 deaths and 13 births since the evacuees' arrival in May 1942. ${ }^{144}$ The high fatality rate forced Dr Raphael Cilento of the Health Department to send a senior officer to investigate. He found rough shelters, poor food supplies and contaminated water, combined with the superintendent's neglect and attitude of indifference towards Aboriginal people, to blame but government officials failed to act. As Ros Kidd notes, places throughout Queensland like Woorabinda were nothing more than 'impoverished communities of impoverished individuals'. ${ }^{45}$

Most of the able-bodied men were quickly sent to work, which Close argues was one of the main reasons for the evacuation. ${ }^{146}$ One news story about Aboriginal people picking peanuts and cotton in Central Queensland supports this argument, but if manpower was in such desperate need, all Aboriginal people would have been either evacuated from the north or otherwise engaged in wartime work. ${ }^{147}$ They were not, and there is insufficient evidence to support this argument as the primary reason for the mission's evacuation. Furthermore, Kidd notes that the cost of evacuations from Cape Bedford and Hammond Island during 1942 forced the Department of Native Affairs to slash subsidies to other missions, which suggests that the financial gains from the labour gained by removal was consumed by the exercise cost. ${ }^{148}$ Only the Cape Bedford people were forcibly 'deported'.

Apart from the reasons for the evacuation, Close's estimation about the size of the labour force is incorrect. Her argument that the government's Manpower Directorate considered the 'influx of additional labour incredibly appealing' and gained 'approximately 250 labourers' as a result of the removal is not supported by records. ${ }^{149}$ As she notes, there were only 36 single men on the mission, and 50 men began work soon after their arrival at Woorabinda. Furthermore, official correspondence from March 1942 listed 170 adults and 100 children at the mission, and obviously not all the adults were capable of full-time employment. ${ }^{150}$ It is likely that 100 workers at most were gained for the war effort as a result of the removal.

143 Kidd 1997: 163-164; Rigsby 1997 says 60 (25 per cent of the Cape Bedford people) died at Woorabinda, while Pearson 1998 states that more than 70 died, including 60 in the first year.

144 Superintendent Woorabinda to Department of Health and Home Affairs, 8 March 1943, QSA, SRS $4326 / 3 / 18$.

145 Kidd 1997: 165.

146 Close 2009: 8.

147 'Aborigines do their bit in war effort', Courier Mail, 8 October 1942: 4.

148 Kidd 1997: 167.

149 Close 2009: 53-55, 65-66.

150 O'Leary to Department of Health and Home Affairs, QSA, SRS 505/1, Box 690. 
John Haviland, who has written much on the mission's history, describes the period at Woorabinda as 'both traumatic and liberating' for the Cape Bedford people, who attended 'ordinary' schools, worked in 'paid employment' and met 'new people' for 'the first time in their lives'. ${ }^{151} \mathrm{He}$ also notes that other Aboriginal people from Cooktown were not evacuated and were 'left to fend for themselves'. ${ }^{152}$ Over 200 Aboriginal people remained around Cooktown for the duration of the war.

According to Noel Pearson, Cape Bedford people retained a separate identity and successfully resisted the entrenched gambling and drinking culture at Woorabinda. ${ }^{153}$ Meanwhile, the missionaries were interned with other 'aliens' at Gaythorne in Brisbane. Schwarz was eventually released on condition that he remained in southern Queensland, and he went to live with his daughter at Eumundi north of Brisbane.

No other Aboriginal mission in North Queensland was forcibly evacuated, and closure was only recommended in one other mission. In April, several weeks before the removal of the Cape Bedford people, the Presbyterian Church Offices at Brisbane wrote to the Office for Civilian Evacuation regarding the evacuation of missionaries. They said a Military Intelligence officer 'insistently advised' the Mornington Island Mission to 'evacuate all white personnel and half caste girls', so the girls were sent to Doomadgee, and the church asked for help with the 'very considerable cost'. ${ }^{154}$ Army HQ at Brisbane reported to Army GHQ at Melbourne about the evacuation of missionaries from Mapoon, Weipa, Aurukun and Mornington Island, saying the Military Intelligence officer who 'gave very strong advice' at Mornington Island was Captain Hall, but there was 'no military pressure' at the other three missions (Mapoon, Weipa and Aurukun). ${ }^{155}$

The Bishop of Carpentaria, Stephen Davies, wrote to the Deputy Director of Native Affairs in June stating 'a Military Intelligence officer, Lieutenant Beaman, visited recently and discussed with him the evacuation of Aboriginals from Cape York Peninsula'. Davies said 'I found that Lieutenant Beaman was forming opinions on insufficient and in some cases inaccurate information'. ${ }^{156}$ O'Leary replied, stating no decision had been made to date, and said: 'You can be assured that the Queensland Government will give the fullest consideration to any suggestions by the Military Authorities but is not likely to act hastily in the evacuation of Peninsula aboriginals' ${ }^{157}$

Kay Saunders regards Beaman's intelligence report, sent in August 1942, as 'influential'. ${ }^{158}$ This reportappears to bethe'SecretMemo' from theFirst Australian Army, sent to the Queensland Public Service Commissioner, providing a priority

151 Haviland 1985: 180.

152 Haviland and Hart 1998: 133.

153 Pearson 2009: 26.

154 Presbyterian Church to Office for Civilian Evacuation, 27 April 1942, NAA, MP 508/1, 82/713/48.

155 Army HQ to Army GHQ, 14 June 1942, NAA, MP 508/1, 82/713/48; AWM, AWM 60, 91/1/4.

156 Bishop Davies to O'Leary, 10 June 1942, QSA, QS 505/1, 1E/18.

157 O'Leary to Bishop Davies, 19 June 1942, QSA, QS 505/1, 1E/18.

158 Saunders 1995: 132. 
list for the evacuation of Aboriginal missions and settlements. According to the list, Cowal Creek and Lockhart River would be the first to be evacuated, followed by Cooktown, then the remaining Gulf and Peninsula centres. ${ }^{159}$ None of these places were evacuated, but a note on a file from $\mathrm{O}^{\prime}$ Leary, stating the Cooktown people 'would probably be safer transferred to Woorabinda as was done with the Cape Bedford aboriginals', suggests one lesson had been learned from the Cape Bedford exercise: 'in any evacuation it is essential that transport be made available for the private effects of individuals' ${ }^{160}$

It is worth stressing the Cape Bedford Mission evacuation was unique in wartime Queensland. Elizabeth Osborne says, and Mark Copland's research on Indigenous removals confirms, that only two other groups were moved in 1942: 90 Hammond Island residents from the Torres Strait were taken to the Darling Downs and over 200 'coloured residents' from Thursday Island were ordered to evacuate to Cherbourg, both in southern Queensland. ${ }^{161}$ Correspondence about removals from Cape York Peninsula later in the war revealed that health, not fear of collaboration with the Japanese, was the main concern but few were removed. ${ }^{162}$

Requests for compensation began in late 1942, when solicitors for the Lutheran Mission Board wrote to the Main Roads Commission. ${ }^{163}$ Five months later the District Engineer reported to Brisbane, saying the church was extended to provide a kitchen, 'the RAAF has occupied the Mission House and will ultimately acquire all buildings', and recommending $£ 23 / 10 /$ - be paid as compensation. The solicitors replied:

We have been in touch with the RAAF in regard to the occupation of the Mission property without making much progress. We are now in touch with the USA Forces who, we understand, are sharing the occupation with the RAAF and trust to make some progress. ${ }^{164}$

American forces took joint control of the airfield late in 1942, but in May 1943 the US Army Supply section wrote to the Department of Native Affairs, saying: 'when the U.S. Army occupied your property at Cooktown, it was in compliance with orders from the proper Australian Army Authorities and it was necessary for the defence of the country at the time'. ${ }^{165}$ One month later, the Australian Army advised: 'no troops under command of this formation have been in occupation of the mission buildings since May 1942'. ${ }^{166}$

159 HQ First Australian Army to Public Service Commissioner, 18 September 1942, QSA, QS 505/1, $1 \mathrm{E} / 18$.

160 O'Leary to Public Service Commissioner, 29 September 1942, QSA, QS 505/1, 1E/18.

161 Osborne 1997: 16, 32; Copland 2005: 118.

162 Copland 2005: 197-198.

163 Chambers, McNab \& Co to Main Roads Commission, 24 September 1942, QSA, 18925 Defence Roadworks Files, 22A-1-85.

164 Chambers, McNab \& Co to Main Roads Commission, 8 May 1943, QSA, 18925 Defence Roadworks Files, 22A-1-85.

165 Army Supply Section to Department of Native Affairs, 22 May 1943, QSA, SRS 505/1/6B/690.

166 HQ First Australian Army to Department of Native Affairs, 27 June 1943, QSA, SRS $505 / 1 / 6 B / 690$. 
It was eventually established that units from the RAAF, US 94th Coastal Battery, the Australian Army and the Allied Works Council had occupied former mission buildings during the construction of the airfield. The army stated they only occupied the mission site for two weeks 'immediately subsequent to the evacuation'. ${ }^{167}$ The sum of $£ 23 / 10 /$ - was accepted from the Main Roads Commission in May 1943. ${ }^{168}$ In 1948, compensation of $£ 3000$, and rent (at $£ 12$ per month) from June 1942, was paid to missionary Schwarz for the Endeavour River land. ${ }^{169}$ A further $£ 455$ was paid to Schwarz in 1952.

Despite the lurid media stories of Lutheran treachery in New Guinea, military authorities soon realised there was no basis for the claims that missionaries had assisted the Japanese. In February 1945, publishers Angus \& Robertson issued a press release advising that 'the first edition of George Johnston's "New Guinea Diary" contained allegations of disloyal conduct by Lutheran missionaries in Papua and New Guinea'. They now stated 'such allegations ... are without foundation'. ${ }^{170}$

In September 1947, Pastor Schwarz and a Lands Department official were flown over the old mission site, and together they chose a new location for the settlement. The third passenger in the plane was a young, recently-elected parliamentarian from the South Burnett area, Johannes Bjelke-Petersen, the chairman of the Hope Vale Mission Board. ${ }^{171}$ He successfully submitted compensation requests to the War Damage Commission and in 1949 persuaded the Labor Government to allow the surviving evacuees at Woorabinda to return home. Pearson observes that some Aboriginal people 'identified him as being the Moses who delivered them from exile' but also notes how Bjelke-Petersen often denied Aboriginal human rights. ${ }^{172}$ Bjelke-Petersen, Queensland's Premier from 1968 to 1987, earned an international reputation as an extreme right-wing conservative politician. Leading Queensland historian Raymond Evans specifically describes the treatment of Indigenous people under his regime: for example, the Aborigines Act 1971 (Qld) was found to have breached 15 articles and sub-clauses of the Universal Declaration of Human Rights. ${ }^{173}$ Health, housing, imprisonment and employment statistics for Aboriginal and Torres Strait Island people in Queensland often caused overseas visitors to express horror and claims of 'apartheid' style race relations.

Finally, after years of absence, the Cape Bedford survivors returned to their own country, and started rebuilding their lives in the new settlement of Hopevale. The trauma of wartime evacuation south was left behind but never forgotten.

167 Department of Native Affairs to Department of Health and Home Affairs, 7 December 1944, QSA, SRS 505/1/6B/690.

168 Chambers, McNab \& Co to Main Roads Commission, 8 May 1943, QSA, 18925 Defence Roadworks Files, 22A-1-85.

169 'Cooktown Aerodrome', NAA, J 56/11, QL687 Pt 2; NAA, A 705, 171/93/743.

170 Angus \& Robertson, 8 February 1945, QSA, SRS 505/1/6B/8/690.

171 Department of Native Affairs, 24 October 1947, QSA, SRS 505/1/4685; Rigsby 1997: 9-10; Townsend 1983: 209.

172 Pearson 1998: 186; 2009: 32.

173 Evans 2007: 233. 
The reasons for the forced removal, and the identities of those who carried it out, are important parts of Australia's and Queensland's history, and should not have remained uninvestigated for so long.

\section{Conclusion}

The coastal steamer Poonbar took the Cape Bedford people from Cooktown on the first step of their journey to Central Queensland, but discovering the reasons for their evacuation, and the identity of those who carried out the order, has taken longer. Uniformed Queensland police supervised by a public servant and three military intelligence officers quickly herded over 200 Aboriginal people from their homes. Although the war between Australia and Japan was the main reason for 'the evacuation of Cape Bedford aboriginals', claims about 'the alleged assistance' given by German missionaries to Japanese forces in New Guinea were eventually proven to be untrue. Despite the argument that 'Authorities' were 'not prepared to take the risk' of Aboriginal collaboration with invaders, removing the Cape Bedford Mission allowed the construction of a strategicallyvital military airfield. ${ }^{174}$

This was the only forced evacuation in Queensland during wartime, and one of only two mass evacuations of Indigenous people in the state during the Second World War. Anxiety about a Lutheran mission, established and staffed by German missionaries, in northern Australia, was used as an excuse to remove all Indigenous people from the Cape Bedford Mission. In central and southern Queensland, some of the men were used to replace European workers who had joined the armed forces, but this labour supply was not the main argument for the evacuation. The risk of Aboriginal collaboration was not credible. There were, as this research has shown, more reasons for the removal than the fear that Aboriginal 'fifth-columnists' might assist a Japanese invasion.

This article has examined three main points. Firstly, the general panic across Australia in 1942 over a threatened Japanese invasion, followed by rumours of German Lutheran missionaries assisting the enemy, claims subsequently proven to be false. Secondly, the unique situation of the people evacuated from the Cape Bedford Mission, rounded up by police during a deportation that was so rushed they were not able to take their personal belongings and essential tools. Thirdly, their traumatic journey south and exile for many years. Finally, as this paper has shown, a military airfield was quickly built on land previously occupied by the mission, suggesting this was the real justification for removal. Military demands for a strategic airstrip were paramount and the fact that construction began one week after the evacuation was approved supports this conclusion.

It seems that the evacuation of the Cape Bedford Mission, supposedly to remove potential enemy sympathisers from an operational area and to make a small supply of labour available for the war effort, was really about using the mission

174 O'Leary to Home Secretary, 23 March 1942, QSA, SRS 505/1/4685, letter 3964 of 1942. 
as a military airfield. This shameful episode deserves to be widely known because, as Andrew Stanfield Sampson accurately noted in 1942, imagine the controversy that would have erupted if the Cape Bedford evacuees were white Australians.

\section{References}

\section{Archival sources}

\section{Australian War Memorial, Canberra}

Australian Army, 'Security - Subversive Activities', AWM 54, Item 243/6/102.

Australian Army, HQ, Queensland, Australian Military Forces, 'Evacuations North Queensland', AWM 60, Items 66/1/88 and 91/1/4.

National Archives of Australia

Australian Army, 'Evacuation of Civilian Population from Vulnerable Areas', MP 508/1, Item 82/713/48.

Australian Army, 'Security of Aerodromes', MP 729/6, Item 25/401/238.

Australian Army, 'Cape Bedford Lutheran Mission', MP 742/1, Item 1/6/204.

Australian Army, HQ, New South Wales, Australian Military Forces, 'Evacuation of Civilian Population', SP1008/1, Item 469/3/41.

Department of Air, 'Cooktown Aerodrome', A 705, Item 171/93/743.

Department of Air, 'Evacuation of Essential Industry and Civilian Population from Vulnerable Areas', A 1196, Item 15/501/239.

Department of Civil Aviation, 'Cooktown Aerodrome', B 595/120, Item 65/97/16, Pt 3.

Commonwealth Investigation Service, 'Behrendorff, Victor', A 1533, Item $1957 / 3354$.

Property and Survey Branch, ‘Cooktown Aerodrome', J56, Item QL687 Pt. 2.

\section{Queensland State Archives}

Commissioner of Police correspondence files, 'Influx of Japanese', A/44700.

Commissioner of Police correspondence files, 'Evacuation of Population', A/73478, 279M4. 
Department of Native Affairs, 'Evacuation Peninsula Aborigines', QS 505/1, $1 \mathrm{E} / 14$.

Department of Native Affairs, 'Evacuation Cape Bedford Mission', SRS $505 / 1 / 4685,6 \mathrm{~B} / 8$, box 690 .

Department of Native Affairs, 'Occupation Cape Bedford Mission', SRS $505 / 1 / 4686,6 \mathrm{~B} / 9$, box 690 .

Harbours batch files, 'Correspondence re Japanese sampans, etc. in northern waters', HAR/69

Health and Home Affairs batch files, 'Native Affairs - Missions 1953', A/58886.

Main Roads Commission, 'Allied Works Council - Cooktown Endeavour River Aerodrome’, 18925 `Defence Roadworks Files', 22A-1-85.

Department of the Premier and Chief Secretary's, correspondence files, 'Papers relating to the Second World War', A/6462, A/6467, A/6472 and A/6478.

Department of the Premier and Chief Secretary, 'Japanese Language Maps', SRS $4848 / 1 / 2$.

Newspapers

Cairns Post

Canberra Times

Courier Mail

Rockhampton Morning Bulletin

Sydney Morning Herald

Townsville Bulletin

West Australian

Main Roads Commission 1949, The History of the Queensland Main Roads Commission during World War II 1939-1945, Main Roads Commission, Brisbane.

Ministry of Defence (NAVY) 1995, War With Japan Volume 1: Background to the War, HMSO, London.

Queensland Government Gazette 


\section{Secondary sources}

Alcorta, Frank 1991, Australia's Frontline: The Northern Territory's War, Allen \& Unwin, Sydney.

Bradley, Vera 2003, I Didn't Know That: Cairns and Districts Tully to Cape York, 1939-1946, Service Personnel and Civilians, Boolarong, Brisbane.

Close, Kirstie 2009, 'Invisible Labourers: Cape Bedford (Hopevale) Mission and the "Paradox" of Aboriginal Labour in the Second World War', unpublished MA thesis, University of Melbourne, Melbourne.

Cobus, Victor and Violet Cobus 1994, Milbi Thagaalbigu Balgaayga (A Story from a Long Time Ago), Guugu Yimithirr Cultural Centre, Hopevale.

Copland, Mark 2005, "Calculating Lives": The Numbers and Narratives of Forced Removals in Queensland, 1859-1972', unpublished PhD thesis, Griffith University, Brisbane.

Donovan, Val 2002, The Reality of a Dark History, Arts Queensland, Brisbane.

Evans, Kay 1972, 'Marie Yamba, Bloomfield and Hope Vale: the Lutheran Missions to the North Queensland Aborigines, 1886-1905', Queensland Heritage 2(6): 26-35.

Evans, Raymond 2007, A History of Queensland, Cambridge University Press, Melbourne.

Falkiner, Suzanne and Alan Oldfield 2000, Lizard Island: The Journey of Mary Watson, Allen \& Unwin, Sydney.

Frei, Henry P 1991, Japan's Southward Advance and Australia From the Sixteenth Century to World War II, Melbourne University Press, Melbourne.

Ganter, Regina 1992, The Pearl-Shellers of Torres Strait, Melbourne University Press, Melbourne.

- 2006, Mixed Relations: Asian-Aboriginal Contact in North Australia, University of Western Australia Press, Perth.

Hall, Robert A 1997, The Black Diggers: Aborigines and Torres Strait Islanders in the Second World War, Aboriginal Studies Press, Canberra.

Haviland, John B 1985, 'The life history of a speech community: Gugu Yimidhirr at Hopevale', Aboriginal History 9(2): 170-204.

- 1996, ‘Owners versus Bubu Gujin: Land Rights and getting the language right in Guugu Yimithirr country', Journal of Linguistic Anthropology 6(2): 145-160. 
Haviland, John B and Leslie K Haviland 1980, “"How much food will there be in Heaven?" Lutherans and Aborigines around Cooktown to 1900', Aboriginal History 4(2): 119-149.

Haviland, John B with Roger Hart 1998, Old Man Fog and the Last Aborigines of Barrow Point, Crawford House Publishing, Bathurst.

Horner, DM 1988, 'Australia under threat of invasion', in Australia: Two Centuries of War E Peace, M McKernan and M Browne (eds), Australian War Memorial with Allen \& Unwin, Canberra.

Hudson, WJ and HJW Stokes (eds) 1982, Documents on Australian Foreign Policy 1937-49, Vol V, Australian Government Publishing Service, Canberra.

Johnston, Mark 2006, Australia's Home Defence, Department of Veterans' Affairs, Canberra.

Kidd, Rosalind 1997, The Way We Civilise, University of Queensland Press, Brisbane.

McIntyre, Darryl 1992, Townsville at War 1942: Life in a Garrison City, Townsville City Council, Townsville.

McIvor, Roy 2010, Cockatoo: My Life in Cape York, Magabala Books, Broome.

Meaher, Augustine IV 2010, The Australian Road to Singapore: The Myth of British Betrayal, Australian Scholarly Publishing, Melbourne.

Moles, Ian 2005, 'Living in the Garrison City: Townsville during World War Two', in Townsville in War and Peace 1942-1946, Geoff Hansen and Diane Menghetti (eds), Townsville Museum and Historical Society, Townsville.

Murray, Jacqui 2004, Watching the Sun Rise: Australian Reporting of Japan, 1931 to the Fall of Singapore, Lexington Books, Lanham.

Oliver, Pam 2010, Raids on Australia: 1942 and Japan's Plans for Australia, Australian Scholarly Publishing, Melbourne.

Osborne, Elizabeth 1997, Torres Strait Islander Women and the Pacific War, Aboriginal Studies Press, Canberra.

Pearson, Noel 1998, 'Ngamu-Ngaadyarr, Muuri-Bunggaga and Midha Mini in Guugu Yimidhirr History: Hope Vale Mission 1900-1950', in Maps, Dreams, History, Jan Kociumbas (ed), Honours thesis, University of Sydney, Sydney.

- 2009, Up From the Mission, Black Inc, Melbourne.

Pohlner, Howard J 1986, Gangurru, Hope Vale Mission Board, Brisbane. 
Potts, E Daniel and Annette Potts 1985, Yanks Down Under 1941-45: The American Impact on Australia, Oxford University Press, Melbourne.

Powell, Alan 2007, The Shadow's Edge: Australia's Northern War, Melbourne University Press, Melbourne.

Richards, Jonathan 2008, The Secret War: A True History of Queensland's Native Police, University of Queensland Press, Brisbane.

Rigsby, Bruce 1997, 'History of the Hopevale Aboriginal Community', unpublished consultant's report, Brisbane.

Ryle, Peter 2000, 'Decline and Recovery of a Rural Coastal Town: Cooktown 1873-1999', unpublished PhD thesis, James Cook University, Cairns.

Saunders, Kay 1995, 'Inequalities of sacrifice: Aboriginal and Torres Strait Islander labour in Northern Australia during the Second World War', Labour History 69: 131-148.

'Schwarz, George Heinrich', German Missionaries in Queensland website, <http:/ / missionaries.griffith.edu.au/biography/schwarz-georg-heinrich>

Sinclair, Don 2005, Cooktown At War, Cooktown and District Historical Society, Cooktown.

Somerville, Margaret 2011, They Crossed a Continent: The Story of a Wartime Exodus from Croker Island to Sydney, Shady Tree, Darwin.

Stanley, Peter 2008, Invading Australia: Japan and the Battle for Australia, 1942, Viking, Melbourne.

Townsend, Derek 1983, Jigsaw: A Biography of Johannes Bjelke-Petersen, Statesman - Not Politician, Sneyd \& Morley, Brisbane.

Unknown 1942, 'War Came To Australia', in Soldiering On: The Australian Army at Home and Overseas, Australian War Memorial, Canberra: 155.

Waters, Damian 2003, Beau's, Butchers and Boomerangs: Mareeba - the History of a WWII Airfield 1942-1945, self-published, Mareeba. 